\title{
STRUKTUR, FUNGSI, DAN NILAI NYANYIAN RAKYAT KAILI
}

\author{
Gazali \\ FKIP Universitas Tadulako \\ email: gazali_lembah@yahoo.co.id
}

\begin{abstract}
Abstrak
Penelitian ini bertujuan mendeskripsikan struktur, fungsi, dan nilai dalam nyanyian rakyat Kaili di Provinsi Sulawesi Tengah. Penelitian dilaksanakan di empat kabupaten/ kota: Donggala, Sigi Biromaru, Parigi-Mautong, dan Palu. Pengumpulan data dengan perekaman, wawancara, dan studi dokumentasi. Analisis data menggunakan ancangan teori hermeneutika Ricouere didukung dengan teori wacana budaya, analisis wacana kritis, analisis isi, teori fungsi nyanyian rakyat, dan teori komponensial nilai. Hasil penelitian sebagai berikut. Pertama, struktur nyanyian rakyat Kaili meliputi struktur makro, superstruktur, dan struktur mikro yang merepresentasikan ideologi kultural masyarakat Kaili. Kedua, nyanyian rakyat Kaili memiliki fungsi ritual, sosial, mendidik, komunikasi dan informasi, dan hiburan. Ketiga, nilai yang terdapat dalam nyanyian rakyat Kaili adalah religius, filsafat, etika, dan estetika.
\end{abstract}

Kata kunci: nyanyian rakyat Kaili, struktur, fungsi, dan nilai

\section{STRUCTURES, FUNCTIONS, AND VALUES OF KAILI FOLKSONGS}

\begin{abstract}
This study aims to describe structures, functions, and values in Kaili folksongs in Central Sulawesi Province. It was conducted in four regencies/cities of Donggala, Sigi Biromaru, Parigi-Mautong, and Palu. The data were collected through recording, interviews, and document study. They were analyzed by means of Ricouere's hermeneutic theory approach supported by cultural discourse theory, critical discourse analysis, content analysis, theory of folksong functions, and componential theory of values. The findings are as follows. First, the structures of Kaili folksongs comprise macrostructure, superstructure, and microstructure representing Kaili people's cultural ideology. Second, Kaili folksongs have ritual, social, educational, communicative and informative, and entertaining functions. Third, values in Kaili folksongs are religious, philosophical, ethical, and esthetic values.
\end{abstract}

Keywords: Kaili folksongs, structures, functions, values

\section{PENDAHULUAN}

Keanekaragaman suku bangsa dengan budayanya di seluruh Indonesia merupakan kekayaan bangsa yang perlu mendapat perhatian khusus. Kekayaan itu mencakup wujud-wujud kebudayaan yang didukung oleh masyarakatnya. Setiap suku bangsa memiliki nilai-nilai budaya khas yang membedakan jati diri mereka dari suku bangsa lain. Perbedaan tersebut akan nyata dalam gagasan-gagasan dan hasil-hasil karya yang akhirnya dituangkan lewat interaksi antarindividu, antarkelompok, dan alam sekitarnya. Berbagai gagasan dan hasil karya tersebut selanjutnya diwariskan kepada masyarakat 
pendukungnya secara turun temurun hingga sekarang dengan bentuk tradisi masing-masing suku bangsa.

Penegakan sistem budaya yang berbasis pada budaya tradisi (budaya daerah) sangat diperlukan, sebab bangsa Indonesia yang relatif multi kultural, multi kekuatan, dan multi kebutuhan. Mempertimbangkan budaya tradisi dalam membangun kebudayaan di masa depan penting karena diyakini pasti banyak nilai yang baik dalam budaya tradisional yang perlu dipertahankan dan dikembangkan. Pengkajian nilai kebudayaan tradisi sebagai salah satu aset bagi pembangunan kebudayaan nasional sangat penting dan strategis. Kebudayaan nasional yang dibangun harus mampu berfungsi sebagai instrumen yang mengakomodasi masa kini dan membuka masa depan pembangunan bangsa yang mengabaikan kebudayaan akan melemahkan sendi-sendi kehidupan bangsa. Pembangunan bangsa yang tidak berdasarkan pada nilai budaya bangsa sendiri akan berakibat pada hilangnya kepribadian dan jati diri bangsa.

Nilai-nilai budaya dalam tradisi dibatasi oleh suku bangsa. Suatu yang dianggap baik dan berharga oleh suatu kelompok masyarakat atau suku bangsa, belum tentu dipandang baik pula oleh kelompok masyarakat atau suku bangsa yang lain. Oleh karena itu, nilai budaya membatasi dan memberikan karakteristik pada suatu masyarakat dan kebudayaannya. Kenyataan alam yang menyebabkan terjadinya perbedaan, resepsi, ekspresi, akulturasi, artikulasi, dan eksternalisasi tentang keselarasan, keindahan, dan kebersamaan.

Perbedaan itu pula yang menyebabkan kayanya budaya di Indonesia. Berbagai khasanah tradisi lisan yang tersebar dari Sabang hingga Marauke memberikan sumber inspirasi untuk membangun dan memperkaya budaya Indonesia. Para pakar tradisi lisan, antara lain Ikram (1990), Ong (1982), Sedyawati, (1996), Pudentia
(1998) mengemukakan bahwa tradisi lisan yang dimiliki, berkembang, dan tersebar dalam masyarakat Indonesia memiliki kedudukan yang mendasar dan sangat penting dalam kehidupan masyarakat pemiliknya.

Seperti halnya tradisi lisan di Nusantara, di Sulawesi Tengah juga terdapat tradisi lisan yang masih didukung oleh masyarakatnya. Tradisi lisan tersebut adalah nyanyian rakyat Kaili (selanjutnya disingkat NRK). Di antara masyarakat penduduk asli yang masih ditemukan menggunakan tradisi lisan tersebut adalah suku Kaili. Suku Kaili adalah salah satu penduduk asli Sulawesi Tengah yang bermukim di sepanjang pantai barat dan timur Sulawesi Tengah. Suku ini umumnya bertempat tinggal di Kota Palu, Kabupaten Donggala, Kabupaten Sigi Biromaru, dan Kabupaten Parigi Mautong. Sebagian menyebar di Kabupaten Tojo Unauna, Poso, Morowali, Banggai, Banggai Kepulauan, Toli-toli, dan Kabupaten Buol. Mereka diikat oleh suatu emosi kesukuan yang meliputi kekerabatan dan kemasyarakatan; kepercayaan; serta bahasa dan kesukuannya. Sebagai suatu kesatuan sosial, mereka memiliki kesamaan norma, nilai, simbol, kepercayaan, dan praktik budaya. Di antara penduduk asli Sulawesi Tengah, seperti Kulawi, Lore, Pamona, Mori, Bungku, Saluan, Balantak, Banggai, Buol, Tolitoli, dan Tomini, suku Kaililah yang paling banyak jumlahnya.

NRK dinyanyikan dalam bentuk tuturan oleh penyanyinya. Melalui tuturan tersebut, mereka mengekspresikan kreativitas dengan memanfaatkan bahasa sebagai wahana tuturnya. Ini menandakan bahwa dalam penuturan tersebut telah terjadi proses komunikasi dengan menggunakan bahasa Sebagai bentuk komunikasi dengan menggunakan bahasa, pengungkapan budaya melalui tuturan lagu dapat dipandang sebagai fenomena wacana (Cook, 1986: 6-7). Melalui wacana tersebut mereka mengungkapkan 
gagasan, perasaan, dan pengalaman budayanya. Kenyataan ini mengisyaratkan bahwa tuturan dalam nyanyian sarat akan norma dan nilai-nilai budaya yang dijunjung tinggi oleh masyarakatnya.

Menurut Sedyawati (1986:4) nyanyian rakyat sebagai seni tradisional merupakan salah satu perwujudan kebudayaan dari satu daerah, di mana wujud tersebut memegang peranan tertentu dalam kehidupan masyarakat pendukungnnya, ia merupakan manifestasi dari kehidupan masyarakat di mana seni tersebut tumbuh dan berkembang. Sebagai bentuk warisan budaya dari suatu masyarakat pendukungnya, seni tersebut merupakan manifestasi dari kehidupan sosial masyarakatnya. Bentuk seni tersebut tidak lain adalah rekaman pikiran, renungan, dan cita-cita masyarakat masyarakat pada waktu tertentu. Kompleks gagasan atau nilai-nilai yang terkandung di dalamnya menjadi landasan perilaku masyarakat yang kehadirannya masih dapat diamati dan dipahami. Nyanyian rakyat tersebut juga memiliki fungsi, seperti yang dikemukakan oleh Chapman (1978) bahwa kehadiran nyanyian bagi masyarakat penuturnya berfungsi sebagai sarana untuk berekspresi atau bersublimasi. Sedangkan secara sosial nyanyian berfungsi untuk memenuhi kepentingan-kepentingan tertentu, antara lain untuk masalah kepercayaan, agama, politik, pendidikan, dan ekonomi. Dalam hal ini tuturan nyanyian mengandung sejumlah pesan yang memiliki fungsi atau makna tertentu bagi masyarakat penuturnya.

Sehubungan dengan penggunaan bahasa dalam nyanyian rakyat tersebut, Suyitno (2007) menyatakan bahwa sebagai bentuk tindak tutur, penggunaan bahasa dalam tuturan lagu terkait erat dengan struktur konteks yang membangun tuturan itu. Hal itu sesuai pula dengan apa yang disampaikan oleh Hymes (1974) bahwa struktur konteks yang menentukan tuturan meliputi latar, partisipan, tujuan, kunci, topik, ragam, dan norma. Dengan demikian, penggunaan bahasa dalam tuturan nyanyian berkaitan erat dengan latar pencapaian tuturan, ciri masyarakat yang menjadi partisipan, tujuan penuturan, pesan-pesan yang dituturkan, dan norma-norma budaya yang dianut. Perbedaan konteks tutur tersebut berimplikasi pada perbedaan pilihan ragam kosa kata, gaya tutur, pesan budaya, dan sikap budaya yang diungkapkan dalam tuturan lagu (Suyitno, 2007). Makna dalam konteks budaya Kaili yang merujuk pada realitas dari pengalaman sehari-hari yang berkaitan dengan aspek-aspek religius, filsafat, etika, dan estetika.

Sebagai produk budaya masyarakat Kaili, NRK disekspresikan melalui bahasa. Beragam kosa kata, gaya bahasa, tuturan, dan bentuk penyajian tuturan dalam nyanyian tersebut merefleksikan nilai budaya masyarakat Kaili. Kosa kata merupakan unsur bahasa yang menjadi kode budaya dan mencerminkan budaya masyarakat pemiliknya. Menurut SapirWorf (dalam Sing, 1999) bahwa tiap-tiap budaya akan menafsirkan dunia dengan cara yang berbeda-beda dan perbedaanperbedaan ini akan terkodekan dalam bahasa. Pernyataan ini dipertegas lagi oleh Sapir (dalam Wardhaugh, 1998) yang mengatakan bahwa corak budaya suatu masyarakat terekam dan tercermin dalam bahasanya. Bertolak dari pikiran tersebut, dapat dikatakan bahwa kosa kata yang membangun NRK merupakan rekaman dan cerminan budaya masyarakat Kaili. Cermin budaya tersebut terangkum dalam struktur NRK yang meliputi struktur makro, superstruktur, dan struktur mikro, yang oleh van Dijk merupakan pisau analisis untuk mengetahui kognisi sosial masyarakat

Sebagai wacana budaya, NRK menampilkan tuturan. Hal ini sesuai dengan hipotesis yang dikemukakan oleh Searle (1983:21) bahwa tuturan merupakan unit dasar komunikasi. Hipotesis tersebut me- 
nyarankan bahwa terdapat serangkaian hubungan analitis antara makna dan tindak tutur dengan maksud penutur, maksud kalimat yang diujarkan, pemahaman mitra tutur, dan kaidah yang mengatur unsur-unsur bahasa. Karena itu, kajian tindak tutur dapat dimanfaatkan sebagai unit kajian wacana budaya. Selanjutnya dipertegas oleh Schiffrin (1994:54) bahwa tindak tutur adalah produk suatu tutran dalam konteks tertentu dan merupakan satuan dasar dari komunikasi bahasa.

Berdasarkan pandangan tersebut, maka representasi nilai dalam NRK dapat dikaji melaui tuturan nyanyian sebagai praktik budaya. Hal ini sejalan dengan pandangan Duranti (1997) yang menyatakan bahwa kaitan bahasa sebagai sumber daya budaya dan bertutur sebagai praktik budaya. Ini berarti bahwa tuturan NRK memuat nilai-nilai yang mencerminkan budaya masyarakat penuturnya. Nilai-nilai tersebut dapat terungkap lebih jelas dengan memanfaatkan pendekatan hermeneutika.

\section{METODE}

Penelitian ini termasuk jenis penelitian kualitatif. Hal ini sesuai dengan kajian yang bersifat deskriptif, eksplanatif, dan eksploratif terhadap NRK. Penelitian ini juga disebut deskriptif interpretatif atau kualitatif intepretatif. Dalam penelitian ini peneliti mengintepretasi pesan dan makna yang terdapat dalam NRK. Interpretasi ini dilakukan dengan dengan memanfaatkan pengetahuan dan pengalaman peneliti terhadap kehidupan sosial budaya masyarakat yang mendukung NRK. Paparan data, cara penjelasan data, maupun pemahaman NRK dilakukan secara mendalam. Kajian NRK dengan ancangan hermeneutika ini berupaya memberikan gambaran interpretatif yang holistik tentang bagaimaana representasi bentuk simbol dan fungsi simbol dalam NRK. Tugas peneliti kualitatif adalah melakukan intepretasi atas intepretasi yang dilakukan oleh seorang pelaku atau sekelompok pelaku terhadap situasi mereka sendiri. Interpretasi dilakukan dengan memperhatikan latar budaya dan sosial tempat penelitian, sesuai saran Robson (1978:16) yang mengemukakan bahwa pengetahuan latar belakang sosial budaya amat penting, karena dengan mengetahui latar belakang sosial budaya tersebut dapat membantu hasil interpretasi yang lebih tepat.

\section{HASIL DAN PEMBAHASAN Struktur Nyanyian Rakyat Kaili}

Struktur nyanyian rakyat Kaili mencakup beberapa aspek, yakni (a) struktur makro, (b) super struktur, dan (c) struktur mikro. Aspek-aspek tersebut diuraikan sebagai berikut.

Pertama, struktur makro. Untuk mengkaji struktur makro dalam NRK dilakukan kajian tematik seperti yang dikemukakan oleh van Dijk dalam teori kognisi sosialnya. Teori kognisi sosial ini didasarkan pada asumsi bahwa teks tidak mempunyai makna, tetapi makna itu diberikan dan diisi oleh pemakai bahasa melalui proses kesadaran mental dari pemakai bahasa. Dijk menghubungkan dua aspek yaitu antara struktur yang sangat mikro berupa wacana dengan struktur masyarakat yang sangat besar. Struktur makro sifatnya tematik yang merepresentasikan tema dan peristiwa secara umum. Elemen tematik tersebut dimaksudkan untuk mengetahui gagasan inti atau yang utama dalam NRK. Dari analisis yang dilakukan, ditemukan beberapa tema dalam NRK yaitu: gotong royong, etika, motivasi, harapan, kritik sosial, kampanye, dan patriotisme.

Kedua, superstruktur. Superstruktur merupakan struktur wacana yang berhubungan dengan kerangka suatu teks, dan bagaimana bagian-bagian teks tersusun dalam wacana. Bagian-bagian teks itu disebut skema wacana, yang menurut Van Dijk (1998) bahwa skema wacana merupakan bentuk global yang biasanya 
dapat dibagi menjadi bagian awal, bagian tengah, dan bagian akhir wacana.

Sehubungan dengan hal tersebut, wacana NRK diuraikan menjadi tiga bagian, yaitu: (1) bagian awal wacana dan ideologi kultural dalam NRK, (2) bagian tengah wacana dan ideologi kultural dalam NRK, dan (3) bagian akhir wacana dan ideologi kultural dalam NRK. Ketiga hal tersebut diuraikan sebagai berikut.

Pada bagian awal disajikan peristiwa awal wacana NRK yang dilakoni oleh aktor (tokoh) yang berperan dalam NRK. Pada nyanyian pengobatan, aktor yang dipresentasikan adalah Toma nubalia, Sando, Tomadua, dan Ibulele. Aktor dalam nyanyian buaian adalah tinanungana dan ngana kodi. Aktor dalam nyanyian duka dan nyanyian dolanan masing-masing adalah sando, dan ngana mpomore. Adapun aktor yang dipresentasikan dalam nyanyian panjang adalah topo dade langgai, topo dade manggubine, dan topo karambanga. Semua tokoh tersebut sangat berperan dalam mengungkapkan ideologi kultural dalam NRK.

Awal wacana NRK dimulai dengan salam pembuka yang ditujukan kepada Tuhan, dan roh leluhur yang dianggap menguasai kehidupan. Salam ini dimaksudkan untuk memohon restu agar nyanyian yang dilakukan para aktor berjalan lancar, mendatangkan berkah, dan memberikan efek magic kepada aktor. Magic adalah suatu yang diyakini dapat menimbulkan kekuatan gaib dan dapat menguasai alam sekitar, termasuk alam pikiran dan tingkah laku manusia. Dalam magic terkandung suatu keyakinan bahwa peristiwa alam tidak digerakkan oleh kehendak atau pikiran suatu mahluk pribadi, tetapi oleh suatu hukum kekal yang bekerja secara mekanis. Efek magic tersebut diharapkan ke dalam jiwa aktor Toma Nubalia (Pimpinan dukun dalam nyanyian pengobatan) agar dapat menyembuhkan aktror tomadua (pasien). Efek magic tersebut selalu dipertahankan dengan cara membakar kemenyan, melantunkan mantra-mantra yang dinyanyikan aktor pendukung lainnya (anggota dukun sebanyak lima orang), serta dukungan aktor Ibulele (penabuh gendang dan peniup suling).

Untuk mengetahui bagian tengah wacana NRK, digunakan kaidah penghilangan (deletion rule), kaidah generalisasi (generalization rule), dan kaidah konstruksi (construction rule). Kaidah penghilangan dimaksudkan untuk menyederhanakan dan menghilangkan bagian wacana yang tidak dibutuhkan. Sedangkan kaidah generalisasi dimaksudkan sebagai upaya untuk menganalisis data yang telah dipilih agar lebih spesifik san kongkret. Adapun kaidah konstruksi dimaksudkan untuk menyusun data generalisasi menjadi data final.

Pada bagian tengah wacana NRK, terjadi interaksi antaraktor dalam menyampaikan inti pesan. Hal itu berbeda dengan bagian awal NRK, di mana aktor hanya melakukan interaksi satu arah yang ditujukan kepada Tuhan, roh leluhur, dan menyapa penonton. Interaksi antartokoh pada bagian tengah NRK membentuk satu alur cerita yang dapat dipahami secara jelas, dan memberikan makna ideologi kultural masyarakat Kaili. Ada lima temuan pada bagian tengah NRK yang dipresentasikan oleh aktor, yaitu (1) riwayat, (2) penghargaan, (3) informasi terkini, (4) kerja sama, dan (5) permohonan.

Pada bagian penutup wacana NRK, tidak lagi terjadi interaksi antaraktor seperti pada bagian tengah wacana NRK, tetapi interaksi dilakukan hanya satu arah saja, yaitu ditujukan kepada penonton.

Representasi ideologi yang dapat dipahami pada bagian penutup NRK tersebut adalah etika dalam bertutur. Dalam melakukan tuturan kepada mitra tutur, seharusnya mengikuti etika tuturan yang meliputi (1) memberi sinyal untuk mengakhiri tuturan kepada mitra tutur, 
sehingga mitra tutur menjadi paham dan tidak lagi melanjutkan tuturannya, (2) menyimpulkan tuturan secara singkat agar informasi yang disampaikan kepada mitra tutur menjadi jelas, dan (3) memohon kepada Tuhan agar apa yang dituturkan mendapat berkah dan memberi manfaat kepada petutur maupun mitra tutur.

Ketiga, struktur mikro dan representasi idelologi NRK. Struktur mikro merupakan makna wacana yang dapat diamati dengan menganalisis kosa kata, pilihan kalimat, dan gaya bahasa yang digunakan dalam wacana. Untuk mengkaji struktur mikro wacana NRK, penulis menganalisis kosa kata dan gaya bahasa NRK. Kosa kata dan gaya bahasa tersebut merepresentasikan ideologi kultural masyarakat Kaili.

Kosakata merupakan unsur bahasa yang menjadi kode budaya dan mencerminkan budaya masyarakat pemiliknya. Sapir-Worf (Singh, 1999) menyatakan bahwa tiap-tiap budaya akan menafsirkan dunia dengan cara yang berbeda-beda, dan perbedaan ini akan terkodekan dalam bahasa. Pernyataan tersebut dipertegas kembali oleh Sapir (Wardhaugh, 1998) yang menyatakan bahwa corak budaya suatu masyarakat terekam dan tercermin dalam bahasanya. Bertolak dari pendapat tersebut, dapat dikemukakan bahwa kosa kata yang membangun tuturan dalam NRK merupakan rekaman dan cermin budaya masyarakat Kaili sebagai penuturnya.

Ditinjau dari ragam dan variasinya, kosakata dalam tuturan NRK dapat dibedakan menjadi dua ragam, yakni ragam kosa kata umum dan ragam kosakata khusus. Ragam kosakata umum adalah ragam kosakata bahasa Kaili yang dimiliki dan digunakan oleh masyarakat Kaili dalam komunikasi sehari-hari, sedangkan ragam kosakata khusus adalah ragam kosakata yang bukan perbendaharaan kata percakapan keseharian bahasa Kaili. Ragam kosakata khusus ini kebanyakan hanya digunakan dalam tuturan lagu dan jarang atau tidak pernah digunakan oleh masyarakat Kaili dalam komunikasi bahasa sehari-hari. Ragam kosakata khusus terdiri dari atas (1) kosakata arkhais, (2) kosakata serapan, dan (3) kosakata khas bahasa Kaili

Gaya bahasa merupakan salah satu unsur yang digunakan dalam seni berbahasa untuk menjadikan karya tersebut memiliki nilai tambah, terutama dari sudut estetis dan kedalaman makna. Penggunaan gaya bahasa dalam NRK juga dimaksudkan untuk keindahan dan kedalaman makna, dan juga sebagai alat untuk merepresentasikan ideologi kultural. Beberapa gaya bahasa yang digunakan dalam NRK adalah: (1) gaya bahasa metafora, (2) gaya bahasa personifikasi, (3) gaya hiperbol, (4) gaya bahasa repetisi, dan (5) gaya bahasa simile

\section{Fungsi Nyanyian Rakyat Kaili}

Fungsi nyanyain rakyat Kaili mencakup: (a) ritual, (b) sosial, (c) mendidik, (d) komunikasi dan informasi, dan (e) hiburan. Fungsi tersebut diuraikan secara terperinci sebagai berikut.

Pertama, fungsi ritual NRK. Ritual merupakan suatu bentuk upacara atau perayaan (celebration) yang berhubungan dengan beberapa kepercayaan atau agama dengan dilandasi sifat khusus, yang menimbulkan rasa hormat yang luhur dalam arti merupakan suatu pengalaman yang suci. Pengalaman itu mencakup segala sesuatu yang dibuat atau dipergunakan oleh manusia untuk menyatakan hubungannya dengan "yang tertinggi", dan hubungan atau perjumpa-an itu bukan suatu yang sifatnya yang biasa atau umum, tetapi suatu yang bersifat khusus atau istimewa, sehingga manusia membuat suatu cara yang pantas guna melaksanakan pertemuan itu.

Terkait dengan fungsi NRK, maka terdapat dua bentuk NRK yang berfungsi sebagai ritual, yaitu nyanyian pengobatan 
dan nyanyian kerja. Pertunjukan nyanyian pengobatan menampilkan beberapa aktor utama dan pendukung untuk mewujudkan ritual pengobatan, begitu pula pada pertunjukan nyanyian kerja. Ritual pengobatan dilaksanakan oleh sejumlah sando (dukun) dengan properti yang melibatkan banyak pendukung. Sedangkan pada nyanyian kerja, ritual dilaksanakan oleh ketua adat atau tokoh masyarakat dan petani untuk memulai suatu pekerjaan membuka lahan pertanian atau perkebunan.

Persiapan pelaksanaan ritual pengobatan dimulai ketika ada warga yang mengalami suatu penyakit yang tidak dapat disembuhkan oleh tenaga medis. Melalui rembug keluarga, maka dilakukan palikiarinoto (ramalan nasib) oleh sando. Hasil ramalan nasib yang dilakukan oleh sando menunjukkan bahwa penyakit tersebut berasal dari leluhur, dan apabila tidak dilakukan ritual pengobatan, maka warga yang sakit tersebut akan terancam jiwanya. Dari hasil palakiarinoto tersebut, maka disiapkan bahan, alat, dan waktu yang tepat untuk pelaksanaan ritual pengobatan.

Berbagai bahan yang disiapkan untuk pelaksanaan ritual tersebut adalah berbagai jenis daun dan bunga, semua jenis pisang yang tumbuh di tanah Kaili, vunja (tiang utama tempat ritual), sakaya (perahu untuk melabuhkan sesajian), tuak, gendang, suling, balida (semacam tongkat sebagai sarana untuk menari), beras empat warna (putih, hitam, merah, dan kuning), payung berwarna kuning, penganan tradisional, dupa, kambing dan ayam sebagai korban yang akan disajikan kepada leluhur. Semua alat dan bahan tersebut telah disiapkan sebelum ritual pengobatan dilakukan.

Ritual pengobatan dimulai ketika toma nubalia (dukun yang memimpin ritual pengobatan) telah siap mengenakan siga dan puruka mbuku (ikat kepala dan pakaian khas dukun) yang diikuti oleh delapan orang dukun lainnya, serta penabu gendang dan peniup suling. Mereka duduk melingkar, sementara sang pasien duduk bersila di tengah-tengah dukun. Sebagai pertanda ritual dimulai dilakukan pembakaran dupa sampai menghasilkan bau harum dari gumpalan asap dupa. Pada saat itu semua sando langgai (dukun pria) meneguk tuak yang telah disiapkan sebelumnya. Pada saat itu semua dukun melakukan pemujaan dan pemanggilan roh leluhur agar masuk ke tubuh mereka. Pemanggilan tersebut dilakukan dengan menyanyikan puji-pujian yang berupa permohonan untuk melakukan ritual pengobatan.

Kedua, fungsi sosial. Nyanyian rakyat memuat banyak hal yang berhubungan dengan kehidupan sosial masyarakat pendukungnya. Ia mengungkapkan kondisi dan situasi sosial-kultural, identitas, dan harapan masyarakat pendukungnya. Hampir semua hasil sastra lisan di nusantara ini mengungkapkan persoalanpersoalan yang menyangkut kehidupan masyarakatnya.

Sehubungan fungsi sosial pada pertunjukan NRK khususnya nyanyian panjang dan nyanyian pergaulan, terjadi interaksi antara penyanyi dengan penonton maupun antara penonton dan penonton. Situasi tersebut selalu terjalin manakala dilangsungkan pertunjukan di setiap kegiatan. Terjalinnya hubungan tersebut karena pada pertunjukan kedua nyanyian itu tidak disiapkan khusus kursi kepada penonton. Penonton bebas memilih tempat dimana ia menyaksikan pertunjukan. Keadaan demikian ini menyebabkan terjadinya interaksi antarwarga tanpa dibatasi oleh status sosial.

Terjalinnya hubungan sosial di tengah masyarakat tidak hanya terjadi pada pertunjukan NRK dilakukan, tetapi pada saat persiapan pertunjukan NRK dilakukan. Pada saat menyiapkan pertunjukan NRK semua warga masyarakat bergotong royong menyiapkan pelaksanaan per- 
tunjukan. Masyarakat tanpa dikomando rela menyiapkan berbagai peralatan dan bahan yang dibutuhkan untuk pertunjukan. Mereka tidak segan-segan mengeluarkan tenaga dan uang untuk sukesnya pertunjukan.

Fungsi sosial dalam NRK, tidak hanya dapat dirasakan pada situasi persiapan dan saat pertunjukannya saja, tetapi yang paling penting adalah isi NRK mengungkapkan berbagai persoalan sosial yang dapat dijadikan teladan sebagai bekal dalam melaksanakan hidup di masyarakat.

Ketiga, fungsi pendidikan. Sastra lisan, khususnya NRK memuat beberapa nilai luhur yang berfungsi untuk pendidikan. Dalam perwujudannya, nilai-nilai luhur itu antara lain terdiri dari nilai religi, nilai filsafat, nilai etika, dan nilai estetika. Nilainilai itu perlu dijadikan landasan pendidikan, khususnya pendidikan moral. Usaha pengangkatan nilai-nilai luhur tersebut didasari oleh anggapan bahwa nilai-nilai itu dapat dipergunakan sebagai upaya penyesuaian diri dengan peradaban dunia masa kini, dalam arti manusia memiliki mentalitas yang mampu menanggulangi tekanan berat yang berupa masalahmasalah yang ada di lingkungannya.

Pendidikan moral yang "mengobati" mental sangat perlu mengingat baik buruknya nasib suatu Negara bergantung kepada mental warganya. Untuk menciptakan mentalitas yang baik itu diperlukan nilai yang memperhalus budi nurani manusia. Sehubungan dengan fungsi pendidikan tersebut, Amir (1990) mengungkapkan bahwa dalam pendidikan diperlukan nilai progresif yang fururistik, juga diperlukan nilai konserfatif (yang digali dari budaya leluhur). Hal tersebut dapat dipahami, mengingat pendidikan nasional kita dilaksanakan dengan maksud agar para siswa dapat maju dan moderen (hidup progresif), mengikuti perkembangan zaman, hidup yang dapat merencanakan masa depan (futuristik), sekaligus juga mencintai budaya dan bangsa sendiri (pendidikan yang nasionalistik). Lebih lanjut Amir (1990:35) mengungkapkan bahwa kita perlu melaksanakan pendidikan sastra yang ideal, yaitu pendidikan sastra yang bersemangat cinta alam dan Tuhan, cinta kemanusiaan dan hidup, idealistikhumanistik, kultural-nasionalistik, dan pendidikan sastra yang imbang. Untuk itu perlu adanya pengkajian terhadap bahanbahan yang diwariskan leluhur kita.

Sehubungan fungsi pendidikan dalam NRK, berikut ini disajikan kutipan NRK yang berfungsi untuk pendidikan, khususnya pendidikan moral.

Keempat, fungsi komunikasi. Fungsi informasi dalam NRK paling banyak dituturkan oleh juru nyanyi. Hal ini disebabkan dalam NRK didominasi oleh pesan dan amanat yang memang merupakan tujuan utama pertunjukan NRK. Data penelitian menunjukkan bahwa pesan dan amanat yang dituturkan menyangkut perihal etika, tanggung jawab, motivasi, hubungan sosial, kejujuran, penghargaan, koreksi diri. dan perihal keadilan.

\section{Nilai dalam Nyanyian Rakyat Kaili}

Nilai yang terdapat dalam nyanyian rakyat Kaili adalah nilai: religius, filsafat, etika, dan estetika. Deskripsi rinci nilai-nilai tersebut diuraikan pada bagian berikut.

Pertama, nilai religius. Nilai religius adalah nilai yang berkaitan dengan keterkaitan antara manusia terhadap Tuhan. Nilai tersebut selalu dijunjung tinggi manusia yang saleh di manapun Ia berada, dalam keadaan susah maupun senang. Seluruh rasa, cipta, dan karsanya bersandar pada nilai tersebut, yang akan membimbingnya menjadi hamba Tuhan yang saleh.

Pada butir ini dipaparkan keterkaitan antara masyarakat Kaili dengan Tuhannya. Keterkaitan tersebut ditandai dengan segala laku perbuatan yang cenderung mengakui keberadaan Tuhan atau yang 
mereka anggap Tuhan. Masya.rakat Kaili yang hampir seluruhnya beragama Islam mengakui keberadaan Tuhan. Namun demikian, dalam hidup hari-hari masih ada sebagian masyarakat Kaili yang dipengaruhi oleh paham Animisme. Hal tersebut dapat dijumpai pada upacara perkawinan, kematian atau upacara daur hidup lainnya. Latar belakang kepercayaan mereka terhadap Tuhan masih didasarkan pada pemikiran totalitas alam sebagai makrokosmos. Dewa-dewa dipuja dipersonifikasikan pada penguasa-penguasa yang langsung mempengaruhi sumber hidup mereka. Yang dipuja adaiah dewa penguasa yang dianggap mempunyai roh yang dapat mereka jadikan media untuk memohon sesuatu.

Nilai religius yang terdapat dialam NRK, meliputi nilai keimantauhidan, nilai peribadatan, dan nilai keichsanan. Nilai keimantauhidan merupakan pengakuan manusia tentang adanya Tuhan. Pengakuan tersebut disadari oleh manusia setelah diperhadapkan pada hal-hal yang di luar kemampuannya. Pada saat tersebut manusia merasa dirinya tidak berarti dibanding kemampuan tersebut. Pengakuan manusia terhadap Tuhan ditandai dengan getaran pada dada yang mengakui bahwa ada sesuatu yang menguasai, yaitu Tuhan. Pengakuan tersebut disertai pula dengan pengakuan sifat-sifat Tuhan yang sempurna, dengan mengakui adanya Tuhan, manusia merasa dekat dengan-Nya dan berusaha mencapai kedekatan yang sempurna.

Untuk mencapai kedekatan yang sempurna pada Tuhan, dibutuhkan pelaksanaan dalam bentuk peribadatan. lbadah adalah ungkapan dari prinsip pokok agama Islam yang merupakan tugas hidup manusia dalam kehidupan di dunia, yang nantinya akan menentukan derajat kedudukan manusia di hadapan Tuhan. Ibadah tersebut terdiri dari ibadah dalam arti khusus dan umum. Ibadah khusus yaitu ibadah yang ditentukan cara-cara serta syarat-syaratnya dalam rangka hubungan khusus antara manusia dengan Tuhan, seperti syahadat, sholat, zakat, puasa, dan naik haji. Sedangkan ibadah dalam arti umum adalah segala kegiatan manusia yang beriman di dalam hidup sehari-harinya yang diinginkan oleh Allah, dikerjakan dengan ikhlas dengan tujuan untuk memperoleh ridah Allah, seperti belajar, berusaha, berkeluarga, bermasyarakat, dan sebagainya.

lbadah manusia terhadap Tuhan dapat mencapai kesempurnaan bila dilakukan dengan penyerahan diri secara total (ichsan) kepada Allah. lchsan sebagai salah satu bagian dari ajaran Islam adalah untuk mengatur dan memperbagus kelakuan manusia. Sebagaimana disabdakan oleh nabi Muhammad, "Jadikanlah ibadahmu kepada Tuhan seakan-akan engkau melihat Dia, jika engkau Tidak melihat Dia, maka dia melihat engkau". Dalam Islam, ibadahlah yang memberikan latihan rohani yang diperlukan manusia. Semua ibadah dalam Islam (ibadah khusus), sholat, puasa, zakat, dan naik haji, bertujuan membuat rohani agar senantiasa tidak lupa pada Tuhan, bahkan senantiasa dekat dengan-Nya. Keadaan senantiasa dekat pada Tuhan sebagai zat yang Maha Suci dapat mempertajam rasa kesucian seseorang. Rasa kesucian yang kuat akan dapat menjadi benteng bagi hawa napsu untuk melanggar nilai-nilai moral, peraturan dan hukum yang berlaku dalam memenuhi keinginannya.

Jalan untuk tetap menjadi suci ialah senantiasa berusaha agar dekat dengan Tuhan. Dengan senantiasa dekat dengan Tuhan, manusia tidak mudah terpedaya oleh kesenangan materi yang akan membawa kepada kejahatan. Dengan senantiasa dekat dan teringat pada Tuhan, manusia akan teringat bahwa kesenangan sebenarnya bukanlah kesenangan sementara di dunia ini, tetapi kesenangan abadi di akhirat. Dengan jalan demikian manusia senantiasa akan berusaha agar tetap 
mempunyai jiwa yang suci dan berusaha untuk menjauhi perbuatan-perbuatan yang tidak baik dan merugikan.

Nilai ikhsan tersebut tidak hanya berkaitan antara manusia dengan Tuhan, tetapi juga antara manusia dengan manusia, manusia dengan alam sekitarnya, dan manusia dengan penghidupannya (diri pribadi).

Kedua, nilai filsafat. Dalam NRK terdapat perenungan dan pemikiran mengenai kehidupan (sehubungan dengan nilai filsatat). Nilai filsatat yang terdapat dalam NRK berbeda dengan nilai filsafat barat yang setiap pemikiran berintikan pertanyaan apakah manusia itu. Dalam filsatat masyarakat Kaili, pertanyaan yang diajukan bukannya apakah manusia itu? melainkan manusia diasumsikan sebagai suatu kenyataan. Dari kenyataan itu barulah diajukan pertanyaan: dari mana asalnya, dan kemana akhirnya manusia itu?

Sehubungan dengan nilai tilsafat tersebut, yang diungkapkan dalam NRK yaitu masalah (1) manusia sebagai makhluk Tuhan, (2) manusia sebagai makhluk sosial, dan (3) manusia sebagai makhiuk pribadi. Keketiga masalah tersebut mengenai cara manusia meiangsungkan hidup, mempertahankan hidup, dan mengembangkan hidup. Nilai filsafat NRK yang mengatur manusia sebagai mahluk Tuhan mengungkapkan kelahiran, jodoh, rezeki, dan kematian.

Nilai filsafat NRK menyangkut manusia sebagai mahluk sosial menggambarkan gambarkan pemikiran dan perenungan yang mengungkapkan bahwa manusia ditakdirkan sebagai makhluk sosial. Sebagai makhluk sosial ia tinggal bersama masyarakat dan hidup bermasyarakat pula, oleh karena itu ia harus menuruti norma, hukum, dan niiai dalam masyarakat itu. Untuk mencapai tujuan hidup sosial yang memiliki harkat, martabat, dan derajad sosial yang tinggi ia harus melaksanakan, mempertahankan, dan mengembangkan hidup sesuai dengan norma, hukum, dan nilai yang benar.

Sehubungan nilai filsafat NRK menyangkut manusia sebagai mahluk pribadi mengungkapkan kewajiban mengembangkan hidup pribadinya. Untuk mengembangkan hidup pribadi tersebut dapat dilakukan secara fisik, nonfisik (mental), dan spiritual. Mengembangkan secara fisik dapat dilakukan berupa membuat rumah, pakaian, dan meningkatkan kesehatan, kebersihan, dan keamanan.

Ketiga, nilai etika. Nilai etika adalah nilai yang mengatur tata kehidupan manusia yang bersumber dari filsafat dan agama. Ia sangat diperlukan manusia dalam melangsungkan kehidupannya, baik sebagai hamba Allah dan khalifah Allah di muka bumi, sebagai makhluk pribadi, dan sebagai mahluk sosial.

Adapun nilai etika yang terdapat dalam NRK meliputi (1) manusia sebagai mahluk Tuhan yang mencakup (a) melangsungkan hidup, (b) taqwa, (c) setia kepada Tuhan, (d) menyatu dengan kehendak Tuhan, (e) pemahaman dan penghayatan terhadap nilai ketuhanan, dan (f) mengamalkan nilai ketuhanan; (2) etika terhadap diri pribadi meliputi: (a) mencintai diri sendiri, (b) hormat dan menghargai diri sendiri, (c) setia pada diri pribadi, (d) menyatu dengan kehidupan pribadi, (e) pemahaman dan penghayatan terhadap nilai pribadi, dan (f) mengamalkan nilai hidup pribadi; (3) etika terhadap sesama manusia mencakup (a) cinta terhadap sesama manusia, (b) hormat terhadap sesama manusia, (c) setia terhadap kehidupan sosial, (d) menyatu dengan kehidupan social, (e) pemahaman dan penghayatan terhadap nilai sosial, dan (f) mengamalkan nilai hidup sosial; (4)

Etika terhadap alam lingkugan mengungkapkan cinta terhadap alam lingkungan.

Keempat, nilai estetika. Nilai estetika dalam NRK mencakup segi isi dan segi bentuk. Dari segi isi, NRK mengungkapkan amanat yang penting dalam kehidu- 
pan. Dari segi bentuk, menyangkut nilai senipertunjukan yang terdiri dari (a) aktor, (b) musik, (c)properti, (d) kostum, (e) pemanggungan, dan (f) penonton.

\section{PENUTUP}

Dari hasil analisis yang dilakukan terhadap NRK disimpulkan sebagai berikut. Pertama, struktur NRK yang meliputi struktur makro, super struktur, dan struktur mikro yang merepresentasikan ideologi kultural masyarakat Kaili. Kedua, fungsi NRK meliputi, (1) fungsi ritual, (2) fungsi sosial, (3) fungsi pendidikan, (4) fungsi informasi, dan (5) fungsi hiburan. Ketiga, nilai religius dalam NRK tidak lengkap. Artinya, dalam nilai tersebut tidak diungkapkan secara lengkap enam rukun iman dan lima rukun Islam. Rukun iman yang diungkapkan adalah (1) pengakuan adanya Tuhan dan sifat-sifat-Nya yang sempurna, (2) pengakuan adanya kitab Allah, (3) pengakuan kerasulan Muhammad, (4) pengakuan adanya hari akhir, dan (5) pengakuan adanya qodo dan qadar Allah. Rukun iman yang tidak diungkapkan adalah percaya pada malaikat Allah. Adapun rukun Islam yang yang diungkapkan adalah (1) sholat, (2) zakat, dan (3) puasa. Sedangkan rukun Islam yang tidak diungkapkan adalah syahadat, dan naik haji.

Berdasarkan hasil analisis dan kesimpulan, dikemukakan saran-saran sebagai berikut. Pertama, penelitian lebih lanjut perlu dilakukan untuk melihat tanggapan dan minat generasi muda masyarakat Kaili terhadap NRK. Berdasarkan pengamatan dan wawancara dengan tokoh masyarakat, ditemui informasi bahwa minat generasi muda masyarakat Kaili terhadap NRK cukup memprihatinkan. Kedua, nilai yang terkandung dalam NRK dapat dijadikan sebagai bahan pembelajaran sastra, khususnya sastra daerah. Guru bahasa dan sastra daerah dapat mempertimbangkan nilai tersebut untuk dijadikan materi pengajaran..

\section{UCAPAN TERIMA KASIH}

Artikel ini disarikan dari disertasi yang berjudul Struktur, Fungsi, dan Nilai Nyanyian Rakyat Kaili di Sulawesi Tengah pada Prgram Pascasarjana Universitas Negeri Malang. Ucapan terima kasih peneliti ditujukan kepada Prof. Dr. Imam Syafi'ie selaku Promotor, Dr. Djoko Saryono, M.Pd. dan Prof. Dr. Abdul Syukur Ibrahim selaku Kopromotor I dan II. Ucapan terima kasih juga disampaikan kepada Dewan Penguji Disertasi yang telah memberikan saran dan masukan yang konstruktif. Ucapan terima kasih peneliti juga ditujukan kepada Direktur DP2M DIKTI yang telah mendanai penelitian ini melalui Hibah Disertasi Doktor.

\section{DAFTAR PUSTAKA}

Amir, H. 1986. "Nilai-Nilai Etis dalam Wayang dan Pendidikan Watak Guru". Disertasi. Malang: PPS IKIP Malang.

Chapman, L.H. 1978. Approach to Art Education. New York: Harcourt Brace Jovanovich Inc.

Cook, G. 1989. Discourse. Oxford University Press.

Duranti, A. 2000. Linguistic Anthropology. Cambridge: University Press.

Hymes, D. 1974. Foundation in Sociolinguisstic: An Ethnographic Approach. Philadelphia: Pennsylvania Press.

Ikram, A. 1984. Perlunya Memelihara Sastra Lama. Dalam Majalah Analisis Kebudayaan. Jakarta: Depdikbud.

Ong, W. J. 1982. Orality and Litercy: The Technologizing of the Word. London: Routledge.

Pudentia, M.P.S.S. 1988. Metodologi Kajian Tradisi Lisan. Jakarta: Yayasan Obor Indonesia

Ricoeur, P. 1985. Hermeneutics and the Human Science. Dalam John B. Thompson (Ed). Canbridge: Canbridge University Press.

Robson, S. O. 1978. Filologi dan SastraSastra Klasik Indonesia. Jakarta: Proyek 
Pengembangan Bahasa dan Sastra Daerah.

Schiffrin, D. 1994. Approaches to Discourse. Oxford, UK, Cambridge: Blackwell.

Searle, John R. 1983. Speech Acts: An Essay in The Philosophy of Language. Cambridge: Cambridge University Press.

Singh, Ishtia. 1999. Language and Ethnicity. Dalam Linda Thomas dan Shan Wareing (Eds). Language, Society, and Power. New York. Routledge.

Suyitno, I. 2007. “Ekspresi Budaya Etnik Using dalam Tuturan Lagu-Lagu Daerah Banyuwangi". Disertasi. Ma- lang: PPS Universitas Negeri Malang.

Sedyawati, Edi. 1996. Kedudukan Sastra Lisan dalam Ilmu-Ilmu Sosial dan IlmuIlmu Budaya. Dalam Jurnal Pengetahuan dan Komunikasi Peneliti Tradisi Lisan.Jakarta: Warta ATL.

Van Dijk, T. 1998. News as Discourse. Hillsdale. New Jersey: Lawrence Eribaum Assosiates.

Wardhaugh, Ronald. 1998. An Introduction to Sociolinguistics. Oxford: Basil Blackkwell 